\title{
THE SOROGAN VERSION OF ACADEMIC MOTIVATION SCALE (AMS-VS) FOR ISLAMIC BOARDING SCHOOL STUDENTS
}

\author{
Aprezo Pardodi Maba ${ }^{1}$, Betty Dwi Pratiwi ${ }^{1}$, Anugrah Intan Cahyani², \\ Muhammad Yusuf ${ }^{1}$ \\ ${ }^{1}$ Fakultas Tarbiyah, Institut Agama Islam Ma'arif NU (IAIMNU) Metro Lampung \\ Jl. RA Kartini No.28, Purwosari, Metro Utara, Kota Metro, Lampung 34114 \\ ${ }^{2}$ Fakultas Tarbiyah, Universitas Islam Negeri Raden Intan Lampung \\ Jl. Letkol H. Endro Suratmin, Sukarame, Kec. Sukarame, Kota Bandar Lampung, Lampung 35131 \\ aprezopm@gmail.com
}

\begin{abstract}
There are many instruments that have been developed by researchers to measure motivation. However, none of the instruments has been specifically designed to measure sorogan motivation on Islamic boarding school students (santri). Therefore, this article was written to discuss the processes of adaptation, testing the validity, and reliability of academic motivation scales to measure sorogan motivation of santri. The authors use Theory of Self Determination (Deci \& Ryan, 1995), Academic Motivation Scale (Vallerand et al., 1992), and AMS Bahasa Indonesia (Natalya \& Purwanto, 2018) as guidelines in compiling indicators, aspects, and items of Academic Motivation Scale Sorogan Version (AMS-VS). Test adaptation guidelines issued by the International Test Commission (2018) are used in adapting the AMS. The data collected from 102 respondents were analysed using Confirmatory Factor Analysis (CFA). The results showed that AMS-VS is a proper and strong measurement to determine the level sorogan motivation of santri.
\end{abstract}

Keywords: academic motivation; Islamic boarding school; santri; sorogan

\begin{abstract}
Abstrak
Ada banyak instrumen yang sudah dikembangkan oleh para peneliti untuk mengukur motivasi. Namun, belum satu pun instrumen secara spesifik dibuat untuk mengukur motivasi sorogan pada santri. Oleh sebab itu, artikel ini ditulis untuk membahas proses adaptasi, pengujian validitas, dan reliabilitas skala motivasi akademik untuk mengukur tingkat motivasi sorogan santri. Penulis menggunakan Teori Determinasi Diri (Deci \& Ryan, 1995), Skala Motivasi Akademik (Vallerand et al., 1992), dan Skala Motivasi Akademik Bahasa Indonesia (Natalya \& Purwanto, 2018) sebagai pedoman dalam menyusun indikator, aspek, dan butir pertanyaan Skala Motivasi Akademik Versi Sorogan (AMS-VS). Panduan adaptasi tes yang dikeluarkan oleh International Test Commission (ITC, 2018) digunakan sebagai pedoman dalam mengadaptasi AMS. Data yang terkumpul dari 102 orang responden kemudian dianalisis menggunakan Confirmatory Factor Analysis (CFA). Hasil penelitian menunjukkan bahwa AMS-VS merupakan alat ukur yang layak dan kuat mengetahui tingkat motivasi sorogan santri.
\end{abstract}

Kata kunci: motivasi akademik; pondok pesantren; sorogan; santri

\section{INTRODUCTION}

Santri salaf is familiar with the sorogan learning method. Santri are students in Islamic boarding schools, while Salafi is students who explore and study ancient books. The sorogan is a typical learning method at an Islamic boarding school that can produce reputable alumni (Muhakamurrohman, 2014). This method's characteristic is one-to-one learning. Each student has the opportunity to read, explain, and recall the previous lesson to the teacher
(Kyai) individually so that the teacher or Kyai can easily evaluate the student's progress (Dhofier, 2011). Students will be better able to absorb the knowledge as much as possible from the teacher, and through the learning process, students will succeed in getting benefits, especially mastery of science.

The sorogan method is effective in improving learning outcomes (Fauzan \& Muslimin, 2018; Salmiah, 2010; Nurjanah, 2018; Wakit, 2016). Outside Islamic 
boarding schools, some scholars developed and applied the sorogan in mathematics learning (Khoiruddin, 2014; Wakit, 2016). However, scholars still find it challenging to implement this method consistently because students must prepare the subjects independently (Dhofier, 2011). Santri, who are not diligent enough, can lose the motivation to perform the sorogan learning method.

In several decades, scholars have used the theory of self-determination approach in various motivational literature (Cokley, 2015). According to the self-determination theory, to be a psychologically healthy individual, a person must have competence, autonomy, and a connection with something to achieve in the future (Deci \& Ryan, 2000). An individual should feel that they determine their actions (autonomy), have closeness to others (connectedness) and can carry out tasks well (competence) (Støen Utvær \& Haugan, 2016). These needs are universally valid, regardless of cultural background and place of living (Deci et al, 2000). Fulfilling these three needs will develop the motivation in performing the task or many activities (Deci et al, 2000).

Schunk \& DiBenedetto (2020) believe that motivation is an essential element for individuals' success because motivation directly affects the effort's intensity in achieving goals. Authors divide motivation into three types Deci \& Ryan (1995). The first is intrinsic motivation. It is an encouragement to perform something important that originates from the self. Intrinsic motivation includes interest, pleasure, and personal satisfaction. It is driven by intrinsic regulation, which is the person's highest quality of motivation (Deci et al, 2000).

The second is extrinsic motivation, characterized by the urge to do something derived from outside the individual, such as honorarium and parents' demands. There are four types of self-regulation that affect extrinsic motivation namely (1) external regulation is an encouragement to do something for getting appreciation from others (Deci \& Ryan, 1985), (2) introjection regulation encourages individuals to accomplish something for avoiding guilt or showing his/her capability (Deci \& Ryan, 2000), (3) the identified regulation is more autonomous regulation but still in extrinsic motivation form. This regulation reflects a person's awareness of his/ her actions and considers the action to be essential, and (4) the most autonomous form of extrinsic motivation is integrated regulation. Integrated regulation occurs when regulations are identified as internalized, which means that these motivations have been evaluated and aligned with their values and needs (Deci et al., 1991). The third is Amotivation, a condition of no encouragement to do something because of the assumption that the set goals are out of reach (Vallerand et al., 1992).

One of the most frequently used instruments in measuring motivation based on selfdetermination theory is the Academic Motivation Scale or AMS (Vallerand et al., 1992). Several existence studies in various countries such as France (Blanchard et al., 1997), Canada (Vallerand et al., 1992), the USA (Osei Akoto, 2014), Italy (Alivernini \& Lucidi, 2008), Turkey (Can, 2015), Norway (Støen Utvær \& Haugan, 2016), and Indonesia (Marvianto \& Widhiarso, 2019; Natalya \& Purwanto, 2018; Wasityastuti et al., 2018) have proven the instrument's validity and reliability. AMS shows good reliability and validity tested on school (Alivernini \& Lucidi, 2008; Bacanlı \& Sahinkaya, 2011; Marvianto \& Widhiarso, 2019; Støen Utvær \& Haugan, 2016) and college students (Orsini, 2015; Can, 2015; Osei Akoto, 2014; Natalya, 2018; Natalya \& Purwanto, 2018; Vallerand et al., 1992; Wasityastuti et al., 2018).

The initial version of AMS consists of seven aspects: knowledge, achievement, stimulation, identified regulation, introjected 
regulation, external regulation, and amotivation (Vallerand et al., 1992). However, in Turkey's testing, only five aspects (motivation, external regulation, introjection regulation, identified regulation, and internal regulation) were used (Alivernini \& Lucidi, 2008). Besides, Bosato (2001) study adapted AMS by changing several sentences in the last version of AMS. Fruthermore, Natalya \& Purwanto (2018) added two alternative items for the amotivation aspect because they considered that the addition of these items was important. Several studies on AMS adapted into Indonesian and published, such as AMS30 and AMS-15 items for college students (Natalya \& Purwanto, 2018) and AMS-28 items for high school students (Marvianto \& Widhiarso, 2019).

Although AMS is a valid and reliable instrument tested in various countries, some researchers claim that AMS has limitations and still needs development, such as further testing in different populations (Alivernini \& Lucidi, 2008; Cokley, 2015; Bacanlı \& Sahinkaya, 2011; Støen Utvær \& Haugan, 2016). Besides, Authors have not found a scale that explicitly measures students' motivation who receive the sorogan education method. Santri is a particular student population that is different from students receiving formal education.

Islamic boarding school has been acknowledged by some people is a subculture in Indonesia's heritage. This is due to the fact that Islamic boarding schools have three distinct aspects, namely the way of life, the values, and the hierarchy of internal authorities which is fully adhered (Karim, 2020). These distinctions made Islamic boarding school students have different characteristics with students from a formal school (Amalia et al., 2020; Aminullah, 2013; Sari, 2019).

The limited literature on the motivation scale in santri's population is an opportunity to research the scale in this particular population. Having a reliable instrument to determine the motivation of students receiving sorogan's learning method can encourage Islamic boarding schools to develop programs according to students' needs. The program is arranged to optimize the learning process so that students can obtain optimal learning outcomes.

According to the limitations, the researcher concludes that a valid, reliable, and contextual motivation scale needs to be developed, especially a scale suitable for students receiving the Sorogan learning method in the Islamic boarding school environment. So, the student's motivation can be measured. Validity and reliability are the main topics in each measurement (Anggraini et al., 2020). This study aims to adapt and modify the AMS items in the Indonesian version (Natalya \& Purwanto, 2018) to measure student sorogan motivation in Islamic boarding school. Authors used seven aspects of AMS (Vallerand et al., 1992) and tested the internal consistency and reliability.

\section{METHOD}

\section{Participants}

Participants in this study were voluntary without any reward. Participants in this study were students who had participated in the sorogan learning method. The authors considered this sampling because the instrument adaptation focused on participants' experiences in participating in the sorogan's learning method. The authors invited students from several Islamic boarding schools in Lampung Province, Indonesia. There were 105 students (male = 44 , female $=61$ ) who confirmed their interest in participating in this study. However, only 102 students (male $=41$, female $=61$; age $M$ $=21.64 ; S D=3.70$ ) were considered to meet the participant criteria because they had followed the sorogan method at Islamic boarding schools. This study uses a 10:1 procedure, at least 10 participants for each variable (Hair et al., 2016). 


\section{Instrument}

The AMS developed by Vallerand et al. (1992) has seven aspects, and each assesses three types of intrinsic motivation (knowledge, achievement, and stimulation), three types of external motivation (identified regulation, introjected regulation, and external regulation), and amotivation. Later, the researcher constructed the seven aspects into 28 items. Each aspect has four items with seven alternative answers $(1=$ absolutely inappropriate to $7=$ absolutely appropriate). The scale is described in the appendix. However, in adapting AMS into Indonesian, Natalya \& Purwanto (2018) added two items of Amotivation aspects so that the final version of AMS in Indonesian was 30 items. Current study modified the AMS-30 Indonesian to the Sorogan Version of Academic Motivation Scale or AMS-VS.

\section{Procedures}

The authors used the Test Adaptation Guide made by the International Test Commission (ITC, 2018). At the Precondition stage, authors could not find copyright holders for the AMS version. However, the authors used AMS with $28+2$ items, adapted and published by Natalya \& Purwanto (2018). The authors asked permission to use the Indonesian version of AMS (See appendix 1) to the previous researcher by sending a message via email.

At the test development stage, the researcher did not translate the AMS English into Indonesian but changed or modified the questions or items of Indonesian version of AMS to the Islamic boarding school cultural context. Furthermore, two experts assessed the suitability of the items with the measurement object and appropriateness with the cultural context of the Islamic boarding school. Invited experts are experienced in instrument adaptation.

In the next step, authors invited two experts who really understand and experience the context of the Islamic boarding school's academic culture. At least ten years work experience in the field, being administrator, and teacher at the Islamic boarding school are the requirements for the invited experts. The questions for the experts are (1) the questions and statements in this scale appropriate for the student at Islamic boarding school? (2) if there is something inappropriate, how should the question be easy to understand and substantial with the context?

After experts' evaluation, the author conducted a readability test by two Islamic boarding school students. The authors asked the students to read the scale and interview them to check their understanding. The interview questions included the easiness of reading and understanding the AMS-VS's questions. After getting input from the students at the readability test and making improvements, the authors added demographic questions, guidelines, and constructing the scoring procedures. AMSVS after expert validation and legibility test is demonstrated in appendix 2.

\section{Data analysis}

Finally, the Authors tested the items' validity and instrument's reliability. This study used confirmatory factor analysis with the LISREL 8.8 application to examine the appropriateness of the measurement design and the compatibility of item's grouping according to their aspects (Mair, 2018; Marsh et al., 2020). The higher the loading value of an item is, the similar and fit the item to the aspect being measured.

The loading value used as a guideline is as follow > .32 is low, > .45 moderate, $>.55$ good enough, > .63 good, and > .71 very good (Tabachnick \& Fidell, 2001). The criteria for fit model followed the fit model test steps, by looking at the $p$-value $>.05$, Root Mean Square Error of Approximation (RMSEA) < .08, Comparative Fit Index $(\mathrm{CFI})>.90$, and Normed Fit Index $(\mathrm{NFI})>$. 90 (Ghozali, 2017). If these criteria for Fit Model do not meet, the authors will use the Modification Index (MI) by correlating the 
error or high Standardize Residual (SR) value (Yamin, 2014).

The authors also measured construct reliability by looking at Average Variance Extracted (AVE) > .5 and Composite Reliability (CR) > .7 (Hair et al., 2016). The authors used the equation guide from Hair et al. (2016) to obtain the AVE (See Equation 1) and CR (See Equation 2).

$$
A V E=\frac{\sum \lambda^{2}}{\sum \lambda^{2}+\sum \theta}
$$

Equation 1.

$$
C R=\frac{\left(\sum \lambda\right)^{2}}{\left(\sum \lambda\right)^{2}+\sum(\theta)}
$$

Equation 2.

\section{RESULTS AND DISCUSSION}

Validation by experts regarding the

suitability of items with Islamic boarding schools' construct and academic conditions resulted in 30 AMS-VS items. Table 1 shows the AMS-VS item. The final items after the expert validation and readability test can be seen in appendix 2. Table 2 shows the results of the CFA test for each aspect of the AMSVS. The factor-loading values for PTH ranged from .79 to .85 with $\mathrm{CR}=.88$ and $\mathrm{AVE}=.66$. The factor-loading values for PEC ranged from .75-.85 CR $=.88$ and AVE $=.66$. STI factor-loading values range from .60 to $.88, \mathrm{CR}=.81$, and $\mathrm{AVE}=.52$. The REKS factor-loading values ranged from .80 to .82 with $\mathrm{CR}=.88$ and AVE $=.66$. The factor-loading values for REIN are between .76 to .85 with $\mathrm{CR}=.88$ and AVE .66. REID factor-loading values are between .58 to .87 with $\mathrm{CR}=.82$ and AVE $=.53$. AMO factor-loading values are between .61 to .83 with $\mathrm{CR}=.86$ and AVE $=.53$. These results indicate that all the items are in accordance with the aspects.

Table 1.

Specification of Sorogan Version of Academic Motivation Scale

\begin{tabular}{clcc}
\hline Aspect & \multicolumn{1}{c}{ Indicator } & Item Number & Total \\
\hline \multirow{4}{*}{ IM } & Intrinsic Motivation to Know (IMTK) & $1,9,16,24$ & 4 \\
& Intrinsic Motivation to Accomplish Things (IMTA) & $2,10,17,25$ & 4 \\
& Intrinsic Motivation to Experienced Stimulation & $3,11,18,26$ & 4 \\
& (IMES) & & \\
\hline \multirow{2}{*}{ EM } & External Regulation (EMER) & $4,12,19,27$ & 4 \\
& Introjected Regulation (EMIN) & $5,13,20,28$ & 4 \\
& Identified Regulation (EMID) & $6,14,21,29$ & 4 \\
\hline AMOT & & $7,8,15,22,23,30$ & 6 \\
\hline
\end{tabular}

Note $. \mathrm{IM}=$ Intrinsic Motivation; $\mathrm{EM}=$ Extrinsic Motivation; AMOT = Amotivation .

At the beginning, the criteria for the fit model were not fulfilled. The authors adjusted and modified the model until the fit model met. Table 2 shows the guidelines of fit model from Ghozali's (2017). From the table, it can be seen that the model used to test the intrinsic motivation aspect (IMTK, IMTA, and IMES) is fit because $p$-value $=.08, p>.05 ;$ RMSEA $=.079<.08 ; \mathrm{CFI}$ $=.982>.90 ; \mathrm{NFI}=.973>.90($ See Figure 1 and Figure 2). The model used to test the extrinsic motivation aspects (EMER, EMIN, and EMID) is also fit because $p$-value $=.12$, $p>.05 ;$ RMSEA $=.074<.08 ;$ CFI $=.988>.90 ; \mathrm{NFI}=.973>.90($ See Figure 3 and Figure 4). Meanwhile, the model used to test the amotivation aspect (AMOT) is fit without any modification, because the $p$ value $=.32>.05 ;$ RMSEA $=.038<.08 ;$ CFI $=1.00>.90 ; \mathrm{NFI}=.98>.90($ See Figure 5$)$. 
Table 2.

CFA for Each AMS-VS Aspect

\begin{tabular}{|c|c|c|c|c|c|c|}
\hline Aspect & Indicator & Item & $\begin{array}{c}\text { Standardize } \\
\text { (estimate) }\end{array}$ & CR & AVE & Model fit \\
\hline \multirow{12}{*}{$\mathrm{IM}$} & \multirow{4}{*}{ IMTK } & IMTK1 & $.85(1.00)$ & \multirow{4}{*}{.88} & \multirow{4}{*}{.66} & \multirow{12}{*}{$\begin{aligned} p \text {-value } & =.08 ; \text { RMSEA }=.079 ; \\
\text { CFI } & =.982 ; \mathrm{NFI}=.973\end{aligned}$} \\
\hline & & IMTK2 & $.82(1.25)$ & & & \\
\hline & & IMTK3 & $.79(.58)$ & & & \\
\hline & & IMTK4 & $.81(.87)$ & & & \\
\hline & \multirow{8}{*}{ IMES } & IMTA1 & $.82(1.00)$ & \multirow{4}{*}{.88} & \multirow{5}{*}{.66} & \\
\hline & & IMTA2 & $.85(1.73)$ & & & \\
\hline & & IMTA3 & $.75(3.81)$ & & & \\
\hline & & IMTA4 & $.83(1.02)$ & & & \\
\hline & & IMES1 & $.69(1.00)$ & \multirow{4}{*}{.81} & & \\
\hline & & IMES2 & $.88(2.67)$ & & \multirow{3}{*}{.52} & \\
\hline & & IMES3 & $.77(1.51)$ & & & \\
\hline & & IMES4 & $.60(.83)$ & & & \\
\hline \multirow{12}{*}{ EM } & \multirow{4}{*}{ EMER } & EMER1 & $.82(1.00)$ & \multirow{5}{*}{.88} & \multirow{4}{*}{.66} & \multirow{12}{*}{$\begin{aligned} p \text {-value } & =.12 ; \mathrm{RMSEA}=.074 ; \\
\mathrm{CFI} & =.988 ; \mathrm{NFI}=.973\end{aligned}$} \\
\hline & & EMER2 & $.82(1.26)$ & & & \\
\hline & & EMER3 & $.80(.59)$ & & & \\
\hline & & EMER4 & $.80(.87)$ & & & \\
\hline & \multirow{8}{*}{ EMID } & EMIN1 & $.80(1.00)$ & & \multirow{5}{*}{.66} & \\
\hline & & EMIN2 & $.85(1.77)$ & \multirow{3}{*}{.88} & & \\
\hline & & EMIN3 & $.76(4.03)$ & & & \\
\hline & & EMIN4 & $.83(1.03)$ & & & \\
\hline & & EMID1 & $.69(1.00)$ & \multirow{4}{*}{.82} & & \\
\hline & & EMID2 & $.87(2.61)$ & & \multirow{3}{*}{.53} & \\
\hline & & EMID3 & $.76(1.49)$ & & & \\
\hline & & EMID4 & $.58(.81)$ & & & \\
\hline \multirow{6}{*}{\multicolumn{2}{|c|}{ AMOT }} & AMOT1 & $.66(1.29)$ & \multirow{6}{*}{.86} & \multirow{6}{*}{.53} & \multirow{6}{*}{$\begin{array}{c}p \text {-value }=.32 ; \text { RMSEA }=.038 ; \\
\text { CFI }=1.00 ; \text { NFI }=.98\end{array}$} \\
\hline & & AMOT2 & $.77(1.49)$ & & & \\
\hline & & AMOT3 & $.61(1.12)$ & & & \\
\hline & & AMOT4 & $.83(1.73)$ & & & \\
\hline & & AMOT5 & $.80(1.56)$ & & & \\
\hline & & AMOT6 & $.80(1.54)$ & & & \\
\hline
\end{tabular}

Note. IM = Intrinsic Motivation; EM = Extrinsic Motivation; AMOT = Amotivation; IMTK = Intrinsic Motivation to Know; IMTA = Intrinsic Motivation to Accomplish Things; IMES = Intrinsic Motivation Experienced Stimulation; EMER = External Regulation; EMIN = Introjected Regulation; EMID = Identified Regulation. 


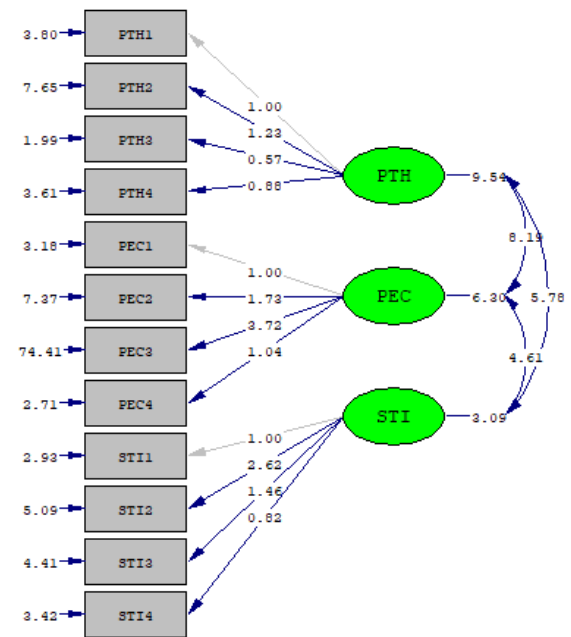

Figure 1. Model 1 Intrinsic Motivation (IM) before fit

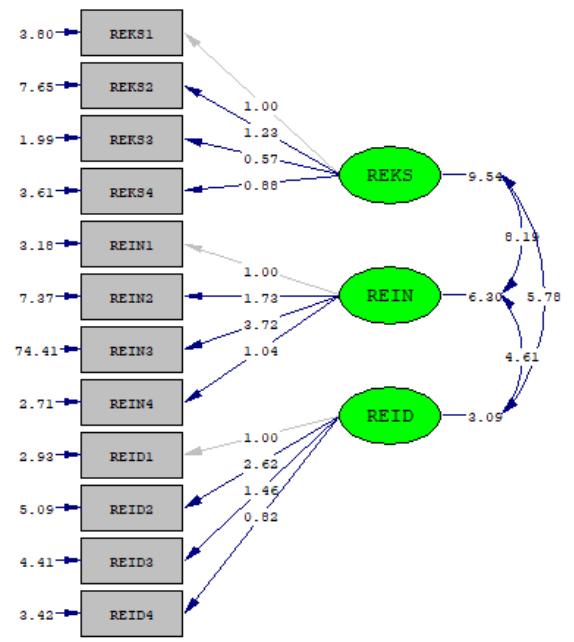

Figure 3. Model 2 Extrinsic Motivation (EM) before fit

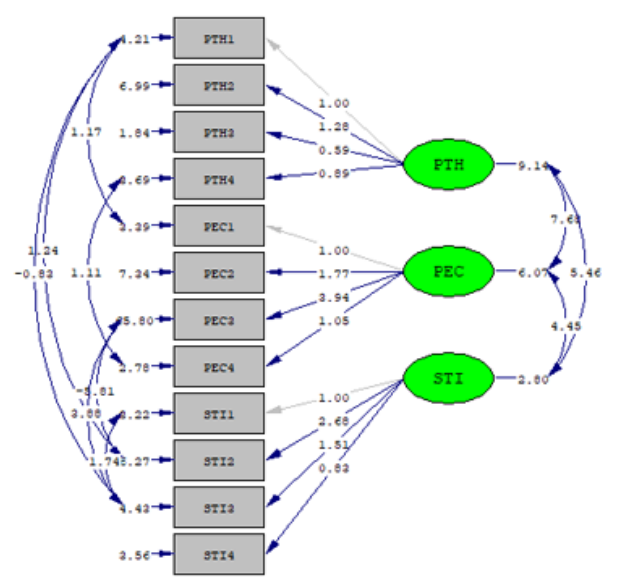

Figure 2. Model 1 Intrinsic Motivation (IM) after fit

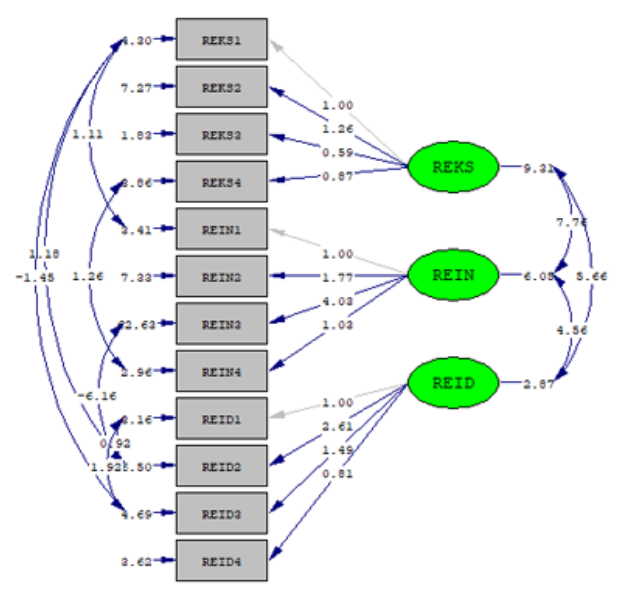

Figure 4. Model 2 Extrinsic Motivation (EM) after fit

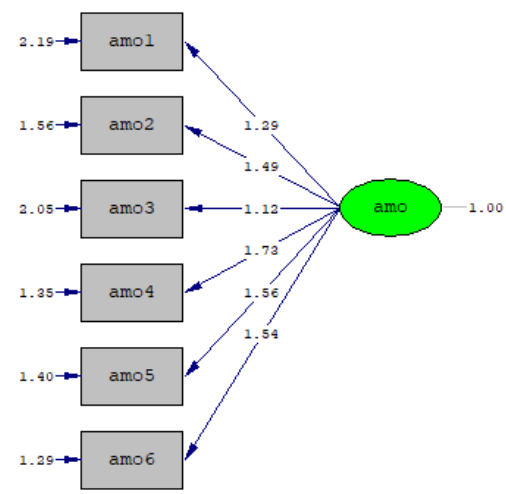

Figure 5. Model 3 Amotivation (AMOT) after fit

The purpose of this study was to test the the expert validated the item's content, and internal validity and reliability of the AMS- the students of Islamic boarding school VS. Before the validity and reliability test, participated in the readability test. Gregory 
(2010) suggests no significant differences between the AMS aspects for the student at school (Alivernini \& Lucidi, 2008; Bacanl1 \& Sahinkaya, 2011; Støen Utvær \& Haugan, 2016) and the university student (Orsini, 2015; Can, 2015; Osei Akoto, 2014; Vallerand et al., 1992). However, in this study, the Authors involved a sample from Islamic boarding schools who get different learning methods and explore different subjects (Shiddiq, 2015). Therefore, the authors concluded the importance of modifying the AMS scale to the AMS-VS with seven aspects that considers the respondents from Islamic Boarding school background.

The CFA test results show that thirty items from the seven aspects of sorogan motivation are good, proper, and support the model with seven aspects in the previous AMS research (Natalya \& Purwanto, 2018; Støen Utvær \& Haugan, 2016). Authors assume that the same mean age and social status of the participants influence the findings.

Although the initial model indicated that the model fit level did not meet the criteria, this problem could be overcome by adding the error relationship in some items with a large standardised residual or modification index (Yamin, 2014). Current study findings showed different results with some prior study, Fairchild et al. (2005) does not have to modify the model. They meet the fit model in the first analysis.

The existence of different findings raises questions about the theoretical basis. The question arises: "do intrinsic and extrinsic motivations not relate, as stated in the theory of self-determination?". De Castella et al. (2013) states that intrinsic and extrinsic motivation are two independent variables, not two variables in one unit as in the selfdetermination theory. To answer this question, studies in this field need to be carried out to reach a consensus on scientists' theory of motivation.
AMS-VS meets the valid construct criteria because the value of the factor-loading items in one aspect is quite balanced, and the findings are similar to previous studies (Smith et al., 2012). AMS-VS has excellent reliability. Some of the CR and AVE values on AMS-VS are higher than the AMS-30 items adapted to Indonesian (Natalya \& Purwanto, 2018) and Norwegian (Støen Utvær \& Haugan, 2016)

The limitation in this finding is the generalization of the scale. The authors' purpose in modifying this scale is that the researcher wants to measure a sample's motivation with a specific background. Therefore, the use of this scale is limited to participants with a santri background. Second, the Authors use a self-report method which allows bias. The respondent's cognitive ability to understand the items or the statement and various other factors can affect the delivery's actual conditions.

The authors suggest enhancing the diversity and number of the participants institution of origin for further study. However, authors believe that this study has a meaningful contribution to literature and scientific advancement, especially in motivation literature. This study also showed that the AMS-VS is a robust instrument for measuring students' motivation. The Islamic boarding schoolteachers can use this instrument to determine the students' motivation in learning with the sorogan method. Besides, the administrators and the authorities of Islamic boarding schools can determine the learning methods policy.

\section{CONCLUSION}

This study adapted the Indonesian AMS-30 items into AMS-VS. The authors tested the AMS-VS to determine its construct validity and reliability using CFA. Based on the fit model's test results, this study found that the AMS-VS with seven aspects were not entirely fit but still could be used after modifying the model by correlating errors or 
high SR values. The item's factor-loading values are fit distributed within the aspects. $\mathrm{CR}$ and AVE scores indicate a high level of reliability. Thus, the authors suggest that AMS-VS are feasible to measure the santri's sorogan motivation in Islamic boarding school.

\section{ACKNOWLEDGMENT}

The authors would like to thank Ms. Lina Natalya from the University of Surabaya for her permission to use the Indonesian version of AMS and her suggestion in improve AMS-VS. Authors also sincere their grateful to Mr. Wahyudi, Ms. Dian Rizky Amalia, and Mr. Agus Setiawan, who has helped the author to perform items validation and calculations in data analysis. As wel as to the participants who involved in this study. Finally, to Institut Agama Islam Ma'arif NU (IAIMNU) Metro Lampung which has allowed the author to conduct this research with ethical clearance number 07/0105/IAIMNU/LPM/XI/2019 and Ministry of Religious Affair fund with contract number 5370 Year 2019.

\section{REFERENCES}

Alivernini, F., \& Lucidi, F. (2008). The academic motivation scale (Ams): Factorial structure, invariance, and validity in the Italian context. TPM, 15(4), https://doi.org/10.4473/TPM.15.4.3

Amalia, D., Rachmah, D. N., \& Mayangsari, M. D. (2020). Perbedaan motivasi berprestasi pada santri pondok pesantren dan peserta didik sekolah umum di Martapura. Jurnal Kognisia: Jurnal Mahasiswa Psikologi Online, 1(2), 3846. https://doi.org/10.20527/jk.v1i2.1545

Aminullah, M. A. (2013). Kecemasan antara siswa SMP dan santri pondok pesantren. Jurnal Ilmiah Psikologi Terapan, 1(2), 205-215-205-215. https://doi.org/10.22219/jipt.v1i2.1578
Anggraini, W., Kurniawan, F., Susilawati, S., \& Hasna, A. (2020). Validitas dan Realibilitas Instrumen Teori Pilihan Karir Holland di Indonesia. Bulletin of Counseling and Psychotherapy, 2(2), 6873. https://doi.org/10.51214/bocp.v2i2.34

Bacanl1, H., \& Sahinkaya, O. (2011). The adaptation study of academic motivation scale into Turkish. Procedia-Social and Behavioral Sciences, 12, 562-567. https://doi.org/10.1016/j.sbspro.2011.02. 068

Blanchard, S., Vrignaud, P., Lallemand, N., \& Dosnon, O. (1997). Validation de léchelle de motivation en éducation aupres de lycéens francais. [Validation of academic motivation scale on a French high school student sample.]. Orientation Scolaire et Professionnelle, 26(1), 33-56. https://psycnet.apa.org/record/199704429-002

Bosato, G. N. (2001). Time perspective, academic motivation, and procrastination [Master's Theses and Graduate Research]. San Jose State Univestity.

Can, G. (2015). Turkish version of the academic motivation scale. Psychological Reports, $\quad 116, \quad 388-408$. https://doi.org/10.2466/14.08.PRO.116k2 4w5

Cokley, K. (2015). A confirmatory factor analysis of the academic motivation scale with black college students. Measurement and Evaluation in Counseling and Development, 48(2), 124-139.

https://doi.org/10.1177/07481756145633 16

De Castella, K., Byrne, D., \& Covington, M. (2013). Unmotivated or motivated to fail? A cross-cultural study of achievement motivation, fear of failure, and student disengagement. Journal of Educational Psychology, 105(3), 861. https://doi.org/10.1037/a0032464 
Deci, E. L., \& Ryan, R. M. (1985). Intrinsic motivation and self-determination in human behavior. Plenum.

Deci, E., \& Ryan, R. (1995). Intrinsic motivation and self-determination in human behaviour. Plenum.

Deci, E. L., \& Ryan, R. M. (2000). The "What" and "Why" of Goal Pursuits: Human Needs and the SelfDetermination of Behavior. Psychological Inquiry, 11(4), 227-268. https://doi.org/10.1207/S15327965PLI1 1 04_01

Deci, E. L., Vallerand, R. J., Pelletier, L. G., \& Ryan, R. M. (1991). Motivation and education: The self-determination perspective. Educational psychologist, 26(3-4), 325-346. https://doi.org/10.1080/00461520.1991.9 653137

Dhofier, Z. (2011). Tradisi Pesantren: Studi Pandangan Hidup Kiai dan Visinya mengenai Masa Depan Islam Indonesia. Jakarta: Penerbit LP3ES, Translation.

Fairchild, A. J., Horst, S. J., Finney, S. J., \& Barron, K. E. (2005). Evaluating existing and new validity evidence for the Academic Motivation Scale. Contemporary Educational Psychology, 30(3), 331-358. https://doi.org/10.1016/j.cedpsych.2004.1 1.001

Fauzan, I., \& Muslimin, M. (2018). Efektifitas Metode Sorogan Dalam Meningkatkan Minat Belajar Santri Di Madrasah Diniyyah Haji Ya'qub Lirboyo Kediri. Intelektual: Jurnal Pendidikan dan Studi Keislaman, 8(1), 69-80. https://doi.org/10.33367/ji.v8i\%601.697

Ghozali, I. (2017). Structural equations model concepts and application with Amos 24 program. Agency Publiher UNDIP.
Gregory, V. L. (2010). Gregory Research Beliefs Scale: Factor Structure and Internal Consistency. Research on Social Work Practice, 20(6), 641-650. https://doi.org/10.1177/10497315093530 49

Smith, K. J., Davy, J. A., \& Rosenberg, D. L. (2012). An empirical analysis of an alternative configuration of the Academic Motivation Scale.Assessment in education: Principles, policy \& practice, 19(2), 231-250.

Hair, J. F., Hult, G., Ringle, C., \& Sarstedt, M. (2016). A primer on partial least squares structural equation modeling (PLS-SEM). SAGE Publications.

Salmiah, S. (2010). Efektivitas penerapan metode sorogan dan bandong dalam proses belajar mengajar: Studi kasus di pondok pesantren putri nuruttaqwa alhasanah bogor. http://repository.uinjkt.ac.id/dspace/handl e/123456789/4413

International Test Commission, I. (2018). ITC Guidelines for Translating and Adapting Tests (Second Edition). International Journal of Testing, 18(2), 101-134.

https://doi.org/10.1080/15305058.2017.1 398166

Karim, B. A. (2020). Strategi Pembelajaran Kitab Kuning (Transformasi Penguatan Sistem Subkultur Pondok Pesantren Indonesia). LPP Unismuh Makassar. Retrieved from http://repository.umi.ac.id/id/eprint/11

Khoiruddin, K. (2014). Pengembangan Model Pembelajaran Kooperatif Tipe Jigsaw Dengan Metode Sorogan Dan Team Teaching Pada Materi Bilangan Di Kelas VII B MTs Nurul Jadid Sidayu [Undergraduate, UIN Sunan Ampel Surabaya]. http://digilib.uinsby.ac.id/1604/ 
Mair, P. (2018). Factor analysis. In Modern Psychometrics with $R$ (pp. 17-61). https://doi.org/10.1007/978-3-31993177-7_2

Marvianto, R. D., \& Widhiarso, W. (2019). Adaptasi Academic Motivation Scale (AMS) versi Bahasa Indonesia. Gadjah Mada Journal of Psychology (GamaJoP), 4(1), 87-95-95. https://doi.org/10.22146/gamajop.45785

Marsh, H. W., Guo, J., Dicke, T., Parker, P. D., \& Craven, R. G. (2020). Confirmatory factor analysis (CFA), exploratory structural equation modeling (ESEM), and set-ESEM: optimal balance between goodness of fit and parsimony. Multivariate behavioral research, 55(1), 102-119. https://doi.org/10.1080/00273171.2019.1 602503

Muhakamurrohman, A. (2014). Pesantren: Santri, Kiai, Dan Tradisi. IBDA`: Jurnal Kajian Islam dan Budaya, 12(2), 109118. https://doi.org/10.24090/ibda.v12i2.440

Natalya, L. (2018). Validation of Academic Motivation Scale: Short Indonesian Language Version. ANIMA Indonesian Psychological Journal, 34(1). https://doi.org/10.24123/aipj.v34i1.2025

Natalya, L., \& Purwanto, C. V. (2018). Exploratory and Confirmatory Factor Analysis of the Academic Motivation Scale (AMS)-Bahasa Indonesia. Makara Human Behavior Studies in Asia, 22(1), 29.

https://doi.org/10.7454/hubs.asia.213011 8

Nurjanah, L. (2018). Efektivitas Penerapan Metode Sorogan terhadap Kemampuan Membaca Kitab Kuning di Pondok Pesantrenal-Hikmah Kedaton Bandar Lampung [Undergraduate, UIN Raden Intan Lampung]. http://repository.radenintan.ac.id/4427/
Orsini, C., Binnie, V., Evans, P., Ledezma, P., Fuentes, F., \& Villegas, M. J. (2015). Psychometric validation of the academic motivation scale in a dental student sample. Journal of dental education, 79(8), 971-981. https://doi.org/10.1002/j.00220337.2015.79.8.tb05989.x

Osei Akoto, E. (2014). Cross-cultural factorial validity of the academic motivation scale. Cross Cultural Management: An International Journal, 21(1), $\quad 104-$ 125. https://doi.org/10.1108/CCM-112011-0100

Sari, W. P. (2019). Gambaran Perbedaan Mekanisme Pertahanan Diri pada Remaja Ditinjau dari Sekolah Umum, Pondok Pesantren dan Panti Asuhan [Undergraduate Thesis, Universitas Medan Area] http://repository.uma.ac.id/handle/12345 6789/10676

Shiddiq, A. (2015). Tradisi Akademik Pesantren. TADRIS: Jurnal Pendidikan Islam, $\quad$ 10(2), 218-229. https://doi.org/10.19105/tjpi.v10i2.826

Schunk, D. H., \& DiBenedetto, M. K. (2020). Motivation and social cognitive theory. Contemporary Educational Psychology, 60, 101832. https://doi.org/10.1016/j.cedpsych.2019.1 01832

Støen Utvær, B. K., \& Haugan, G. (2016). The Academic Motivation Scale: Dimensionality, Reliability, and Construct Validity Among Vocational Students. Nordic Journal of Vocational Education and Training, 6(2), 17-45. https://doi.org/10.3384/njvet.2242458X.166217

Tabachnick, B. G., \& Fidell, L. S. (2001). Using Multivariate Statistics (4 ed.). Allyn and Bacon. 
Vallerand, R. J., Pelletier, L. G., Blais, M. R., Briere, N. M., Senecal, C., \& Vallieres, E. F. (1992). The Academic Motivation Scale: A measure of intrinsic, extrinsic, and amotivation in education. Educational and psychological measurement, 52(4), 1003-1017. https://doi.org/10.1177\%2F00131644920 52004025

Wakit, A. (2016). Efektivitas Metode Sorogan Berbantuan Tutor Sebaya Terhadap Pemahaman Konsep Matematika. JES-MAT (Jurnal Edukasi dan Sains Matematika), 2(1). https://doi.org/10.25134/jes-mat.v2i1.278

Wasityastuti, W., Susani, Y. P., Prabandari, Y. S., \& Rahayu, G. R. (2018). Correlation between academic motivation and professional identity in medical students in the Faculty of Medicine of the Universitas Gadjah Mada Indonesia. Educación Médica, 19(1), 23-29. https://doi.org/10.1016/j.edumed.2016.12 .010

Yamin, S. (2014). Rahasia olah data Lisrel. Mitra Wacana Media. 
Appendix 1.

Bahasa Indonesia version of AMS (Natalya \& Purwanto, 2018)

1. Saya berpendapat bahwa saya perlu lulus kuliah agar mendapatkan pekerjaan dengan gaji tinggi.

2. Saya merasakan kenikmatan dan kepuasan saat mempelajari hal baru.

3. Saya merasa kuliah ini berguna untuk karir yang saya inginkan.

4. Saya benar-benar menikmati pelajaran/materi yang ada selama kuliah ini.

5. Terus terang saja, saya tidak tahu kenapa saya harus mempelajari bidang ini.

6. Entahlah, saya merasa bahwa kuliah hanyalah membuang-buang waktu.

7. Saya menikmati upaya untuk memahami hal-hal yang sebelumnya tidak saya pahami.

8. Untuk membuktikan pada diri saya sendiri, bahwa saya bisa berhasil dalam perkuliahan.

9. Supaya saya mendapat pekerjaan yang bergengsi nantinya.

10. Saya senang menemukan hal-hal yang belum pernah saya ketahui sebelumnya.

11. Perkuliahan memungkinkan saya mendapatkan pekerjaan yang saya sukai.

12. Karena bagi saya, kuliah ini menyenangkan.

13. Dulu saya memang punya alasan untuk belajar, tapi sekarang saya tidak tahu apakah saya perlu terus belajar untuk kuliah ini.

14. Saya senang ketika berusaha melampaui target-target pribadi saya.

15. Karena saya akan merasa penting jika berhasil dalam perkuliahan.

16. Karena saya ingin bisa hidup nyaman nanti setelah selesai kuliah.

17. Untuk merasakan kenikmatan saat mengetahui lebih banyak tentang topik-topik yang menarik.

18. Perkuliahan ini akan membantu saya membuat keputusan yang lebih baik tentang orientasi karir saya.

19. Saya menikmati proses pada saat saya berdiskusi dengan dosen.

20. Saya tidak tahu kenapa saya mengambil kuliah di bidang ini.

21. Saya tidak peduli dengan perkuliahan ini.

22. Untuk kepuasan yang saya rasakan saat berusaha menyelesaikan tugas/aktivitas yang sulit.

23. Untuk menunjukkan pada diri saya sendiri bahwa saya memang pandai.

24. Agar saya bisa mendapat gaji yang tinggi ketika bekerja.

25. Karena perkuliahan ini membuat saya belajar tentang banyak hal baru yang menarik.

26. Karena saya percaya bahwa kuliah ini akan meningkatkan kompetensi untuk pekerjaan yang ingin saya tekuni.

27. Karena saya merasa sangat senang saat membaca berbagai topik menarik terkait perkuliahan.

28. Entahlah, saya tidak tahu mengapa saya perlu hadir di kelas.

29. Karena perkuliahan ini memberi saya kepuasaan personal dari proses untuk menguasai materinya secara mendalam.

30. Karena saya ingin memperlihatkan pada diri saya bahwa saya bisa berhasil dalam studi. 
Appendix 2.

The Sorogan Version of Academic Motivation Scale (AMS-VS)

1. Saya merasakan kenikmatan dan kepuasan saat belajar dengan metode sorogan

2. Saya menikmati upaya untuk memahami hal-hal yang sebelumnya tidak saya pahami dengan metode sorogan

3. Saya benar-benar menikmati belajar kitab kuning dengan metode sorogan

4. Saya merasa belajar dengan metode sorogan berguna untuk menguasai materi kitab kuning

5. Untuk membuktikan kepada diri saya sendiri, bahwa saya bisa berhasil dalam belajar kitab kuning menggunakan metode sorogan

6. Saya berpendapat bahwa saya perlu belajar kitab kuning dengan metode sorogan agar dapat memahami materinya dengan baik

7. Terus terang saja, saya tidak tahu kenapa saya harus belajar dengan metode sorogan

8. Saya tidak peduli dengan metode belajar sorogan

9. Saya senang menemukan hal-hal yang belum pernah saya ketahui sebelum saya belajar dengan morode sorogan

10. Saya senang ketika berusaha melampaui capaian belajar dengan menggunakan metode sorogan

11. Karena bagi saya, belajar dengan metode sorogan adalah hal yang menyenangkan

12. Belajar menggunakan metode sorogan memungkinkan saya mendapatkan nilai yang saya inginkan

13. Karena saya akan merasa penting jika berhasil belajar kitab kuning dengan metode sorogan

14. Supaya saya dapat membangun pondok pesantren sendiri nantinya

15. Entahlah, saya merasa bahwa belajar dengan metode sorogan hanyalah membuangbuang waktu

16. Untuk merasakan kenikmatan saat mengetahui lebih banyak tentang materi yang menarik dengan metode sorogan

17. Untuk kepuasan yang saya rasakan saat berusaha menyelesaikan tugas membaca kitab kuning yang sulit

18. Saya menikmati proses pada saat berdiskusi tentang salah satu kajian dalam kitab kuning dengan guru/ustadz

19. Belajar menggunakan metode sorogan membatu saya membuat keputusan yang lebih baik untuk masa depan saya

20. Untuk menunjukkan kepada diri saya bahwa saya memang pandai mengaji kitab kuning dengan metode sorogan

21. Supaya saya dapat diangkat menjadi salah satu pengurus pondok pesantren

22. Dulu saya memang punya alasan untuk belajar, tapi sekarang saya tidak tahu apakah saya perlu terus belajar dengan metode sorogan

23. Entahlah, saya tidak tahu mengapa saya perlu ikut belajar dengan metode sorogan

24. Karena belajar dengan metode sorogan membuat saya belajar tentang banyak hal baru yang menarik

25. Karena belajar dengan metode sorogan memberi saya kepuasan pribadi dari proses menguasai materinya secara mendalam

26. Karena saya merasa sangat senang saat ditugaskan membaca berbagai materi menarik dalam kitab kuning sebelum melakukan sorogan

27. Karena saya percaya bahwa metode sorogan dapat meningkatkan kompetensi saya dalam memahami materi mengaji yang diberikan 
28. Karena saya ingin memperlihatkan pada diri saya bahwa saya bisa berhasil mengaji kitab kuning hingga khatam

29. Agar saya mendapatkan barokah dari Allah SWT

30. Saya tidak tau kenapa saya belajar dengan metode sorogan 